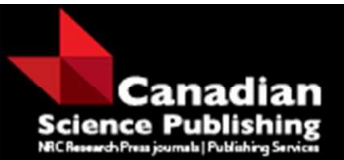

Canadian Journal of Forest Research

Revue canadienne de recherche forestière

\title{
Seasonal availability of inoculum of the Heterobasidion root disease pathogen in central Wisconsin
}

\begin{tabular}{|r|l|}
\hline Journal: & Canadian Journal of Forest Research \\
\hline Manuscript ID & cjfr-2016-0136.R1 \\
\hline Manuscript Type: & Note \\
\hline Date Submitted by the Author: & 24-May-2016 \\
\hline Complete List of Authors: & $\begin{array}{l}\text { Stanosz, Glen; University of Wisconsin-Madison, Forest and Wildlife } \\
\text { Ecology } \\
\text { Smith, Denise; University of Wisconsin Madison, Forest and Wildlife } \\
\text { Ecology } \\
\text { Juzwik, Jennifer; USDA Forest Service }\end{array}$ \\
\hline Keyword: & $\begin{array}{l}<\mathrm{i}>\text { Heterobasidion }</ \text { i }>,<i>\text { irregulare }</ \text { i }>\text {, inoculum, }<\text { i }>\text { Pinus }</ \text { i }>, \\
<i>\text { resinosa }</ i>\end{array}$ \\
\hline & \\
\hline
\end{tabular}

SCHOLARONE ${ }^{\text {It }}$

Manuscripts 
4 Glen R. Stanosz, Department of Forest and Wildlife Ecology, University of Wisconsin-

5 Madison, 1630 Linden Drive, Madison, WI, 53706, USA, gstanosz@wisc.edu

6

7 Denise R. Smith, Department of Forest and Wildlife Ecology, University of Wisconsin-

8 Madison, 1630 Linden Drive, Madison, WI, 53706, USA, drsmith4@wisc.edu

9

10 Jennifer Juzwik, Northern Research Station, USDA Forest Service, 1561 Lindig Ave.,

11 St. Paul, Minnesota, 55108, USA, jjuzwik@fs.fed.us

12

13 For correspondence:

14 Glen R. Stanosz

15 Department of Forest and Wildlife Ecology

16 University of Wisconsin-Madison

171630 Linden Drive, Madison, WI, 53706, USA

18 telephone: 608-265-2863

19 fax: 608-262-9922

20 email: gstanosz@wisc.edu 


\section{Abstract}

2 After deposition of airborne basidiospores, the root disease pathogen Heterobasidion

3 irregulare infects fresh conifer stumps and spreads through root grafts or by root contact to

4 adjacent trees. Infection can be prevented, however, by borate application. Because the need

5 for stump protection depends on inoculum availability, spore trapping was conducted

6 (usually biweekly) from September 2009 through December 2011 in three infested

7 plantations of predominantly red pine (Pinus resinosa) in central Wisconsin. A semi-

8 selective medium in Petri plates was exposed for 1 hour in daylight at each of four locations

9 in each plantation. After 7-10 days incubation at $20^{\circ} \mathrm{C}$ plates were examined and presence

10 and abundance of colonies of the Spiniger asexual stage were recorded. H. irregulare was

11 detected on most dates during the two growing seasons, but colonies were most abundant

12 during late summer, fall, and early winter. Relatively fewer colonies developed on medium

13 exposed during periods of coldest winter temperatures, but colonies of the pathogen did

14 develop frequently on medium exposed at $\leq 5^{\circ} \mathrm{C}$ and occasionally on medium exposed at $\leq 0$

$15{ }^{\circ} \mathrm{C}$. Biologically based guidelines for stump treatment require additional studies of seasonal

16 factors influencing inoculum availability, in situ spore germination, infection, and

17 establishment of the pathogen.

18

19 Key words: Heterobasidion irregulare, inoculum, Pinus resinosa 


\section{Introduction}

The fungal pathogen Heterobasidion irregulare Garbelotto and Otrosina is a recently

3 described species in the former H. annosum sensu lato species complex (Otrosina and

4 Garbelotto 2010). Although reported hosts or substrates of $H$. irregulare include a variety of

5 conifer species in both eastern and western North America (Sinclair 1964), this species was

6 previously referred to as the intersterility group P (for pine, Pinus L.) of H. annosum

7 (Otrosina and Garbelotto 2010). After infection of fresh conifer stump surfaces following

8 deposition of airborne basidiospores, $H$. irregulare spreads through root grafts or by root

9 contact to adjacent trees, to result in expanding root disease centers. Thus, high incidence of

10 H. irregulare and severe damage that can include growth loss and mortality of pines has

11 frequently occurred following thinning of commercial pine plantations in the southern United

12 States (Mason 1969; Powers and Hodges 1970; Bradford et al. 1978a, 1978b). As is known

13 for other Heterobasidion root disease pathogens, application of protective chemicals

14 including urea and borates or the biocontrol fungus Phlebiopsis gigantea (Fr. : Fr.) Julich can

15 prevent infection that occurs after deposition of $H$. irregulare spores on freshly cut stumps

16 (Berry and Bretz 1964; Ross and Hodges 1981; Dumas and Laflamme 2013).

Detection or quantification of basidiospore inoculum of Heterobasidion species in

19 forests is commonly accomplished by exposure of conifer stem disks or culture media. After

20 incubation, confirmation of the presence of these fungi is possible due to production of

21 conidiophores with conidia of their asexual Spiniger Stalpers stage (Brefeld 1888; Stalpers

22 1974). These methods have been employed by many previous researchers for pathogen

23 detection and investigations of seasonal and spatial variation in presence of inoculum of 
1 Heterobasidion species in both Europe and North America (e.g.: Rishbeth 1951; Kallio 1970;

2 Stambaugh et al. 1962; Boyce 1963; Sinclair 1964; Möykkynen et al. 1997; Ross 1970;

3 Edmonds et al. 1984; Gonthier et al. 2005).

4

6 (Stanosz et al. 1995), this pathogen has been found much more widely in that state.

7 Heterobasidion root disease is now known to occur in at least 24 of 72 Wisconsin counties,

8 most frequently damaging highly productive plantations of red pine (Pinus resinosa Aiton)

9 (Wisconsin Department of Natural Resources 2015). Red pine is the most commonly planted

10 conifer species in the Great Lakes region of the United States, where it is most commonly

11 managed in single species, even-aged plantations (Gilmore and Palik 2006). Pulp, lumber,

12 and utility poles are produced in economic rotations of 55 to 90 years with thinning at regular

13 intervals, but the red pine is long lived and can reach ages of 200 years or more. At the end

14 of a rotation, stands are typically replanted with red pine seedlings following either complete

15 overstory removal or with retention of small numbers of overstory trees. Among other

16 common economically and ecologically important conifer species in the Great Lakes region

17 that are proven or potentially significant hosts of $H$. irregulare are eastern white pine $(P$.

18 strobus L.), jack pine (P. banksiana Lamb.), balsam fir (Abies balsamea (L.) P. Mill.),

19 eastern hemlock (Tsuga canadensis (L.) Carrière), northern white-cedar (Thuja occidentalis

20 L.), eastern red-cedar (Juniperus virginiana Sarg.), white spruce (Picea glauca (Moench)

21 Voss), black spruce (P. mariana (Miller) B.S.P.), and tamarack (Larix laricina (Du Roi) K.

22 Koch).

23 
Almost 20 years after discovery in the state, the Wisconsin Department of Natural

2 Resources provided a "risk-based guide for the fungicide treatment" to prevent

3 Heterobasidion root disease (Wisconsin Department of Natural Resources 2013). A stump

4 protectant currently available in the United States is a borate material applied in water either

5 manually or through the heads of harvesting equipment (Cellutreat ${ }^{\circledR}$, Nisus Corp., Rockford,

$6 \quad \mathrm{TN})$. Current, local information regarding seasonal variation in presence and abundance of

7 inoculum of $H$. irregulare in North America is limited, however, and these have not been

8 investigated in the Great Lakes region of the United States. The following study was

9 undertaken to obtain data that might assist managers to both justify and increase efficiency of

10 efforts to prevent Heterobasidion root disease in that region. Spores were trapped on a semi-

11 selective medium in Petri plates that were exposed in infested red pine plantations at regular

12 intervals for 28 months, including during periods of sub-freezing winter temperatures.

\section{Materials and methods}

15 Spore trapping was attempted (usually biweekly except as noted in Fig. 1) during

16 September 2009 - December 2011 in mature, commercial red pine plantations in central

17 Wisconsin counties of Waushara (44.20, -89.24), and Marquette (43.67, -89.35) and

18 November 2009 - December 2011 in Portage County (44.58, -89.53). Sites were flat or

19 gently sloping at elevations of 240-340 m above sea level with well-drained sand, loamy

20 sand, or sandy loam soils (USDA Natural Resources Conservation Service 2013). These

21 soils are relatively infertile and prone to drought in the summer and were historically often

22 occupied by xeric pine forests and scrub oak communities (Curtis 1959). The climate is

23 continental with low to moderate levels of precipitation, cool-to-warm summers, and cold 
1 winters (Moran and Hopkins 2002). Except for temperature during each brief period of spore

2 trapping (as described below), weather conditions at these plantations were not monitored.

3 However, available weather data and snow depths recorded at nearby weather recording

4 stations were obtained (Wisconsin State Climatology Office 2016) and are summarized in

5 Table S1.

6

$7 \quad$ Each plantation had been thinned at least twice without treatment to prevent stump

8 infection, and was known to be infested with $H$. irregulare. The identity of the pathogen at

9 these sites was confirmed by comparing ITS sequences from each of 14 isolates (4-6 per site)

10 obtained from host material to ITS sequence for the well-characterized $H$. irregulare strain

11 TC32-1 (GenBank accession FJ627586) (Olson et al. 2012). Sequence data from each of

12 these isolates was greater than 99\% similar to sequence data of strain TC32-1 (data not

13 shown). At each site four red pine stumps that bore basidiocarps of $H$. irregulare at the start

14 of the study were used throughout as locations for placement of spore traps. Spore traps

15 consisted of 9-cm-diameter Petri plates with semi-selective medium (20 g agar, 5 g Bacto-

16 peptone, $0.5 \mathrm{~g} \mathrm{KHPO}_{4}, 0.51 \mathrm{~g} \mathrm{MgSO}_{4}, 1000 \mathrm{ml} \mathrm{H}_{2} \mathrm{O}$, plus the following added after

17 autoclaving: $2 \mathrm{ml} \mathrm{50 \%} \mathrm{lactic} \mathrm{acid,} \mathrm{and} \mathrm{both} 0.1 \mathrm{~g}$ streptomycin sulfate and $0.19 \mathrm{~g}$

18 pentachloronitrobenzene suspended in $10 \mathrm{ml}$ 95\% EtOH) (modified from Kuhlman and

19 Hendrix 1962). On each date of sampling one plate was placed on each of the four selected

20 stumps in each plantation and opened to expose the medium for 1 hour during which there

21 was no measurable precipitation. All three sites were sampled in succession during daylight

22 on the same day. A digital thermometer was placed next to one stump at each site to monitor

23 temperature during the 1-hr exposure period. Plates were closed, brought to the laboratory, 
1 and after 7-10 days incubation at approximately $20^{\circ} \mathrm{C}$ were examined using a dissecting

2 microscope at approximately $30 \mathrm{x}$ magnification. If necessary, slides were prepared and

3 examined using a compound microscope at up to $400 \mathrm{x}$ magnification.

The number of plates deployed at each site on each date on which H. irregulare was

6 identified after incubation was recorded. These data were plotted by date and correlations of

7 these data among sites were tested using Minitab Release 14.1 (Minitab Inc., State College,

8 PA). Numbers of colonies of this fungus per plate were recorded as $0,1-10,11-20$, or $\geq 21$,

9 and these data also were plotted by date.

\section{Results}

12 Although a variety of fungi (not identified) did develop on the exposed medium,

13 radial growth was somewhat restricted to allow distinct colonies to be examined. After 7-10

14 days colonies of hyaline $H$. irregulare hyphae were $\leq 5 \mathrm{~mm}$ in diameter and thin, appearing

15 transparent to faintly white. Characteristics of the Spiniger asexual conidiophores and

16 conidia borne at their swollen apices allowed differentiation of $H$. irregulare colonies from

17 others with similar morphology.

19 The number of plates for each date on which H. irregulare was identified were

20 correlated among the three sites (values of $r$ for pairwise comparisons $\geq 0.65$ ). Further, due

21 to similarity among sites in the number of colonies per plate on respective dates, a pattern is

22 evident (Fig. 1). Spores were frequently trapped and were often most numerous in late

23 summer and fall. For example, if each discrete $H$. irregulare colony detected originated from 
1 a single spore, deposition resulting in one or 20 colonies on medium exposed for 1 hour in a

29 -cm-diameter Petri plate (area of approximately $64 \mathrm{~cm}^{2}$ ) is equivalent to approximately 160

3 or 3200 , respectively, viable spores deposited $\mathrm{m}^{-2} \cdot$ hour $^{-1}$. Colonies of H. irregulare also

4 developed, though less abundantly than in autumn, on plates exposed in spring and summer

5 months beginning as early as April in 2010 and 2011. Trapping of spores, sometimes in very

6 large numbers, continued into December of each year. At least 21 colonies of $H$. irregulare

7 were recorded for multiple plates exposed at two of the three sites in mid-December 2011,

8 but numbers of positive plates and colonies per plate diminished at all three sites in mid-

9 December 2009 and 2010 after persistent snow cover (Figure 1 and Table S1). Spores were

10 infrequently trapped during months of January - March 2010, and were not trapped during

11 those months in 2011. However, spores were trapped on numerous dates in winter when

12 temperatures recorded during exposure remained $\leq 5{ }^{\circ} \mathrm{C}$ or even $\leq 0{ }^{\circ} \mathrm{C}$ (Table 1 , Table S1).

\section{Discussion}

15 Knowledge of the availability of $H$. irregulare inoculum gained during this study

16 should contribute to recognition of the increasing risk posed by Heterobasidion root disease

17 to forests of the Great Lakes region. Not only were viable spores trapped during much of the

18 growing season (and some winter periods), they were sometimes very abundant. Thus, there

19 is great potential for inoculation of additional unprotected, fresh stump surfaces in already

20 infested stands and also in adjacent areas during much of the year. Further investigation of

21 the possibility of inoculum dissemination during winter, especially during periods of mild

22 weather, and implications regarding infection are justified. 
The pattern of seasonal variation in availability of $H$. irregulare inoculum observed at

2 all three sites of this study is generally similar to that often described for other

3 Heterobasidion root disease pathogens. Gonthier et al. (2005) investigated Heterobasidion

4 species spore deposition in four forests of the western Alps and found that "inoculum

5 concentration consistently peaked in late summer or early fall." The very large numbers of

6 spores deposited in our study were sometimes much greater that those reported in two studies

7 of deposition of $H$. irregulare inoculum in the northeastern US (Sinclair 1964, Stambaugh et

8 al. 1962). Well-documented influences of local, temporal environmental factors on both

9 inoculum production and dispersal (Sinclair 1964, Kallio 1970) that were not within the

10 scope of this study, and a steep, decreasing gradient in deposition of Heterobasidion

11 inoculum with increasing distance from sources (e.g., Kallio 1970, Möykkynen 1997) also

12 are likely sources of such differences. Results could also be affected by differences in

13 trapping efficiency and ease of pathogen recognition between pine stem disks or stumps

14 (used in those studies) and Petri plates of a semi-selective medium. However, our results

15 might still underestimate Heterobasidion inoculum availability that can occur under the most

16 conducive conditions. For example, Kallio (1970) reported deposition equivalent to $>45 \mathrm{x}$

$1710^{6}$ spores $^{\bullet} \mathrm{m}^{-2} \cdot$ hour $^{-1}$ on agar exposed for just 5 seconds under H. annosum sensu lato

18 basidiocarps.

The observed availability of Heterobasidion inoculum early in the growing season in

21 central Wisconsin is consistent with reports from numerous, widely distributed European

22 studies (e.g., East Anglia, England, Rishbeth 1951; southern Finland, Kallio1970; western

23 Italian Alps, Gonthier et al. 2005). Although knowledge from research in northern temperate 
1 forests of eastern North America is much more limited, early spring fertility of basidiocarps

2 was reported by Sinclair (1964). Of those collected at various sites in New York state from

3 mid-April to mid-June, $23 \%$ bore mature basidia and basidiospores. Additionally, red pine

4 stem disks were exposed as spore traps in an infested plantation of Scots pines (P. sylvestris

5 L.) and red pines near Varna, New York $(42.46,-76.44)$ from late June to mid-October 1960

6 and early June to mid-November 1961. Although the highest deposition rates occurred in

7 late summer and fall, deposition of over 1000 viable spores $\mathrm{m}^{-2} \cdot$ hour $^{-1}$ occurred on two

8 different dates in June in one of the two years of that study. Thus, H. irregulare inoculum

9 from basidiocarps produced the previous fall and that have survived relatively harsh winter

10 conditions is likely to occur and occasionally be abundant, even in very early spring.

12 Development of colonies from spores deposited on plates exposed at low and

13 subfreezing temperatures also indicates survival of mature basidia with basidiospores with at

14 least potential for periodic dissemination during winter. Abundant discharge of H. annosum

15 sensu lato basidiospores after a period of cold weather during which minimum air

16 temperatures ranged from $-3{ }^{\circ} \mathrm{C}$ to $-7^{\circ} \mathrm{C}$ was reported by Rishbeth (1951). Kallio (1970)

17 noted an occasion on which basidiospores were trapped at $-1.0{ }^{\circ} \mathrm{C}$. Basidiospores trapped at

18 subfreezing temperatures in our study may have matured during an earlier, warmer period

19 and were simply dislodged by air currents during the hour of subfreezing exposure of spore

20 traps. Alternatively, incident solar radiation may warm a basidiocarp sufficiently to allow

21 discharge. 
Although winter dissemination and subsequent basidiospore germination and conifer

2 stump infection by Heterobasidion pathogens in northern forests may be less frequent when

3 harvesting is accomplished in winter, it does occur. For example, Thor and Stenlid (2005)

4 investigated efficacy of materials and methods used to treat Picea abies (L.) Karst stumps

5 from both summer and winter thinning in stands infested by H. annosum sensu lato in

6 southern to central Sweden. Several weeks after trees were cut, disks were cut from stump

7 surfaces and incubated in the laboratory. In spite of development of substantially smaller

8 Heterobasidion colonies on most disks from the winter-thinned stumps, the probability of

9 infection of these stumps was approximately 0.1. Comparable studies are lacking in northern

10 portions of eastern North America with severe winters. In a more southern site, however,

11 Stambaugh et al. (1962) investigated infection of eastern white pine stumps resulting from

12 winter thinning in the Tuscarora State Forest $(40.30,77.59)$ of Pennsylvania. Frequency of

13 stump infection was $\geq 70 \%$ for stumps from the December, January, and February thinnings,

14 even when maximum recorded temperatures were usually $\leq 5^{\circ} \mathrm{C}$, sometimes did not exceed

$150{ }^{\circ} \mathrm{C}$, and when minimum recorded temperatures were well below $0{ }^{\circ} \mathrm{C}$.

17 The prolonged availability of $H$. irregulare inoculum is relevant in the context of the

18 response to its detection and current proliferation in Wisconsin, and also the very recent

19 report of Heterobasidion root disease in neighboring Minnesota (Blanchette et al. 2015). The

20 Wisconsin Department of Natural Resources "risk-based guide for the fungicide treatment"

21 to prevent Heterobasidion root disease (Wisconsin Department of Natural Resources 2013)

22 has been developed using very limited knowledge of $H$. irregulare biology or host and

23 environmental influences on disease development in the Great Lakes region. Presumably 
1 due to the practical difficulty in application of a water-borne chemical in winter, treatment is

2 recommended from April 1 to November 30, but not after November 30 "except under

3 unusual weather patterns." Examples provided include "prolonged unusually warm weather

4 during the winter period (Dec 1- Mar 31)." Dissemination of viable basidiospores during this

5 period, including at subfreezing temperatures, is the first requirement for infection of fresh

6 stumps when left untreated in winter. The potential for survival of either winter-deposited $H$.

7 irregulare inoculum or incipient colonies of the pathogen in stumps resulting from winter

8 thinning in the Great Lakes region, and contribution to continued proliferation, is a subject of

9 ongoing studies.

\section{Acknowledgements}

12 The authors gratefully acknowledge private landowners and Wisconsin Department

13 of Natural Resources for access to infested plantations, and the USDA Forest Service Special

14 Technology Development Program for partial financial support (project NA-2009-02).

\section{References}

17 Berry, F.H., and Bretz, T.W. 1964. Urea and other chemicals effective against colonization

18 of shortleaf pine stumps by Fomes annosus in Missouri. Plant Dis. Reptr. 48: 886-887.

20 Blanchette, R.A., Held, B.W., Mollov, D., Blake, J., and D’Amato, A.W. 2015. First report

21 of Heterobasidion irregulare causing root rot and mortality of red pines in Minnesota. Plant

22 Disease 99: 1038. 
1 Boyce, J.S., Jr. 1963. Colonization of pine stem sections by Fomes annosus and other fungi

2 in two slash pine stands. Plant Dis. Reptr. 47: 320-324.

3

4 Bradford, B., Alexander, S.A., and Skelly, J.M. 1978a. Determination of growth loss of

5 Pinus taeda L. caused by Heterobasidion annosus (Fr.) Bref. Eur. J. For. Path. 8: 129-134.

7 Bradford, B., Alexander, S.A., and Skelly, J.M. 1978b. Incidence and severity of annosus

8 root rot in loblolly-pine plantations in Virginia. Eur. J. For. Path. 8: 135-145.

10 Brefeld, O. 1888. Untersuchungen aus dem Gesammtgebeiete der Mykologie, Heft 8.

11 Leipzig, Germany.

12

13 Curtis, J.T. 1959. The Vegetation of Wisconsin: An Ordination of Plant Communities.

14 University of Wisconsin Press, Madison, WI. 657 p.

16 Dumas, M.T., and Laflamme, G. 2013. Efficacy of two Phlebiopsis gigantea formulations in

17 preventing Heterobasidion irregulare colonization of red pine stumps in eastern Canada.

18 Phytoprotection 93: 25-31.

19

20 Edmonds, R.L., Hinshaw, R.W., and Leslie, K.B. 1984. A 24-hour deposition sampler for

21 spores of Heterobasidion annosum. Phytopathology 74: 1032-1034. 
1 Gilmore, D.W., and Palik, B.J. 2006. A revised managers handbook for red pine in the North

2 Central Region. USDA For. Serv. Gen. Tech. Rep. NC-264.

3

4 Gonthier, P., Garbelotto, M.M., and Nicolotti, G. 2005. Seasonal patterns of spore deposition

5 of Heterobasidion species in four forests of the western Alps. Phytopathology 95: 759-767.

6

7 Kallio, T. 1970. Aerial distribution of the root-rot fungus Fomes annosus (Fr.) Cook in

$8 \quad$ Finland. Acta Forestalia Fennica 107: 55 p.

9

10 Kuhlman, E.G., and Hendrix, F.F., Jr. 1962. A selective medium for the isolation of Fomes

11 annosus. Phytopathology 52: 1310-1312.

12

13 Mason, G.N. 1969. An evaluation of the incidence of Fomes annosus in East Texas. Plant

14 Dis. Rptr. 53: 936-939.

16 Moran, J.M., and Hopkins, E. J. 2002. Wisconsin's Weather and Climate. University of

17 Wisconsin Press, Madison, WI. 376 p.

18

19 Möykkynen, T., von Weissenberg, K., and Pappinen, A. 1997. Estimation of the dispersal

20 gradients of S- and P-type basidiospores of Heterobasidion annosum. Eur. J. For. Path. 27:

$21291-300$.

22

23 Olson, Å., Aerts, A., Asiegbu, F., Belbahri, L., Bouzid, O., Broberg, A., Canbäck, B., 
1 Coutinho, P.M., Cullen, D., Dalman, K., Deflorio, G., van Diepen, L.T.A.,

2 Dunand, C., Duplessis, S., Durling, M., Gonthier, P., Grimwood, J., Fossdal, C.G.,

3 Hannson, D., Henrissat, B., Hietala, A., Himmelstrand, K., Hoffmeister, D., Högberg, N.,

4 James, T.Y., Karlsson, M., Kohler, A., Kües, U., Lee, Y-H., Lin, Y-C., Lind, M., Lindquist,

5 E., Lombard, V., Lucas, S., Lundén, K., Morin, E., Murat, C., Park, J., Raffaello, T., Rouzé

6 P., Salamov, A., Schmutz, J., Solheim, H., Ståhlberg, J., Vélëz1, H., de Vries, R.P.,

7 Wiebenga, A., Woodward, S., Yakovlev, I., Garbelotto, M., Martin, M., Grigoriev, I.V., and

8 Stenlid, J. 2012. Insight into trade-off between wood decay and parasitism from the genome

9 of a fungal forest pathogen. New Phytol. 194: 1001-1013.

11 Powers, H.R., Jr., and Hodges, C.S., Jr. 1970. Annosus root rot in eastern pines. USDA For.

12 Serv. For. Pest Leaflet 76.

14 Otrosina, W.J., and Garbelotto, M. 2010. Heterobasidion occidentale sp. nov. and

15 Heterobasidion irregulare nom. nov.: A disposition of North American Heterobasidion

16 biological species. Fungal Biol. 144: 1-25.

18 Rishbeth, J. 1951. Observations on the biology of Fomes annosus with particular reference

19 to East Anglian pine plantations. II. Spore production, stump infection, and saprophytic

20 activity in stumps. Ann. Bot. 15: 1-21. 
1 Ross, E.W. 1970. Fomes annosus in the southeastern United States: relation of environmental

2 and biotic factors to stump colonization and losses in the residual stand. USDA For. Serv.

3 Tech. Bull. 1459.

4

5 Ross, E.W., and Hodges, C.S., Jr. 1981. Control of Heterobasidion annosum colonization in

6 mechanically sheared slash pine stumps treated with Peniophora gigantea. USDA For. Serv.

$7 \quad$ Res. Pap. SE-229.

8

9 Sinclair, W.A. 1964. Root- and butt-rot of conifers caused by Fomes annosus, with special

10 reference to inoculum dispersal and control of the disease in New York. Memoir 391 of the

11 Cornell University Agricultural Experiment Station, New York State College of Agriculture,

12 Ithaca, NY. 54 p.

13

14 Stalpers, J.A. 1974. Spiniger, a new genus for imperfect states of basidiomycetes. Proc.

15 Koninkl. Nedl. Akad. Wetensch. (Ser. C) 77: 402-407.

16

17 Stambaugh, W.J., Cobb, F.W., Jr., Schmidt, R.A., and Krieger, F.C. 1962. Seasonal inoculum

18 dispersal and white pine stump invasion by Fomes annosus. Plant Dis. Reptr. 46: 194-198.

19

20 Stanosz, G.R., Guthmiller, M.A., and Kearby, W.H. 1995. Root-rot of red pine caused by

21 Heterobasidion annosum in Wisconsin. Plant Dis. 79: 859. 
1 Thor, M., and Stenlid, J. 2005. Heterobasidion annosum infection of Picea abies following

2 manual or mechanized stump treatment. Scand. J. For. Res. 20:154-164.

3

4 USDA Natural Resources Conservation Service. 2013. Web Soil Survey [online]. Available

5 from : http://websoilsurvey.sc.egov.usda.gov/App/HomePage.htm [accessed 8 March 2016].

6

7 Wisconsin Department of Natural Resources. 2015. Wisconsin DNR Forest Health 2015

8 Annual Report [online]. Available from

9 http://dnr.wi.gov/topic/ForestHealth/documents/AnnualReport2015.pdf [accessed 8 March $102016]$.

11

12 Wisconsin Department of Natural Resources. 2013. A risk-based guide for the fungicide

13 treatment to prevent annosum root rot in Wisconsin [online]. Available from

14 http://dnr.wi.gov/topic/foresthealth/documents/AnnosumTreatmentGuide.pdf [accessed 8

15 March 2016].

16

17 Wisconsin State Climatology Office. 2016. Climate Data from National Weather Service

18 Reporting Stations [online]. Available from http://www.aos.wisc.edu/ sco/clim-

19 history/acis_stn_meta_wi_index.htm [accessed 26 April 2016].

20 
1 Table 1. Detection of $H$. irregulare (x) on semi-selective agar medium in at least one of the

2 four Petri plates exposed for approximately 1 hour during which temperatures did not exceed

$35{ }^{\circ} \mathrm{C}$ or $0{ }^{\circ} \mathrm{C}$ on various dates over 28 months at three sites in central Wisconsin.

\begin{tabular}{|c|c|c|c|c|c|c|c|c|c|c|c|c|c|c|c|}
\hline \multirow[b]{2}{*}{ Temperature } & \multirow[b]{2}{*}{ Site } & \multicolumn{14}{|c|}{ Date } \\
\hline & & $\begin{array}{l}2 \\
0 \\
z \\
z \\
0 \\
0\end{array}$ & 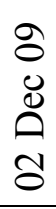 & $\begin{array}{l}8 \\
0 \\
0 \\
0 \\
0 \\
0\end{array}$ & $\begin{array}{l}0 \\
\text { ే } \\
\text { : } \\
0\end{array}$ & $\begin{array}{l}0 \\
\text { 으 } \\
\text { స్ } \\
\stackrel{0}{0}\end{array}$ & $\begin{array}{l}0 \\
0 \\
0 \\
0 \\
0\end{array}$ & $\begin{array}{l}0 \\
0 \\
\stackrel{\nu}{0} \\
0 \\
0\end{array}$ & $\begin{array}{l}0 \\
\stackrel{0}{0} \\
\stackrel{\nu}{0} \\
n\end{array}$ & $\begin{array}{l}0 \\
\mathcal{U} \\
\stackrel{\Xi}{0} \\
\infty \\
\text { N }\end{array}$ & $\begin{array}{l}z \\
z \\
z \\
0\end{array}$ & $\begin{array}{l}= \\
z \\
z \\
0\end{array}$ & $\begin{array}{l}z \\
z \\
z \\
0 \\
m\end{array}$ & $\begin{array}{l}= \\
0 \\
0 \\
n \\
n\end{array}$ & $\begin{array}{l}= \\
u \\
\stackrel{d}{0} \\
\infty \\
\sim\end{array}$ \\
\hline \multirow{3}{*}{$\leq 5^{\circ} \mathrm{C}$} & Portage Co. & $\mathrm{x}$ & $\mathrm{x}$ & & & & & $\mathrm{X}$ & & & $\mathrm{x}$ & $\mathrm{X}$ & $\mathrm{x}$ & $\mathrm{x}$ & \\
\hline & Waushara Co. & & $\mathrm{X}$ & & & $\mathrm{x}$ & & $\mathrm{X}$ & $\mathrm{X}$ & & & $\mathrm{X}$ & $\mathrm{x}$ & & $\mathrm{X}$ \\
\hline & Marquette Co. & & $\mathrm{x}$ & $\mathrm{x}$ & $\mathrm{x}$ & & $\mathrm{X}$ & $\mathrm{X}$ & $\mathrm{x}$ & $\mathrm{X}$ & & $\mathrm{X}$ & $\mathrm{x}$ & $\mathrm{X}$ & $\mathrm{x}$ \\
\hline \multirow{3}{*}{$\leq 0{ }^{\circ} \mathrm{C}$} & Portage Co. & & & & & & & $\mathrm{x}$ & & & & & & $\mathrm{x}$ & \\
\hline & Waushara Co. & & & & & $\mathrm{x}$ & & $\mathrm{X}$ & $\mathrm{x}$ & & & & & & \\
\hline & Marquette Co. & & & $\mathrm{X}$ & $\mathrm{X}$ & & $\mathrm{X}$ & $\mathrm{X}$ & $\mathrm{X}$ & $\mathrm{X}$ & & & & & \\
\hline
\end{tabular}

4 


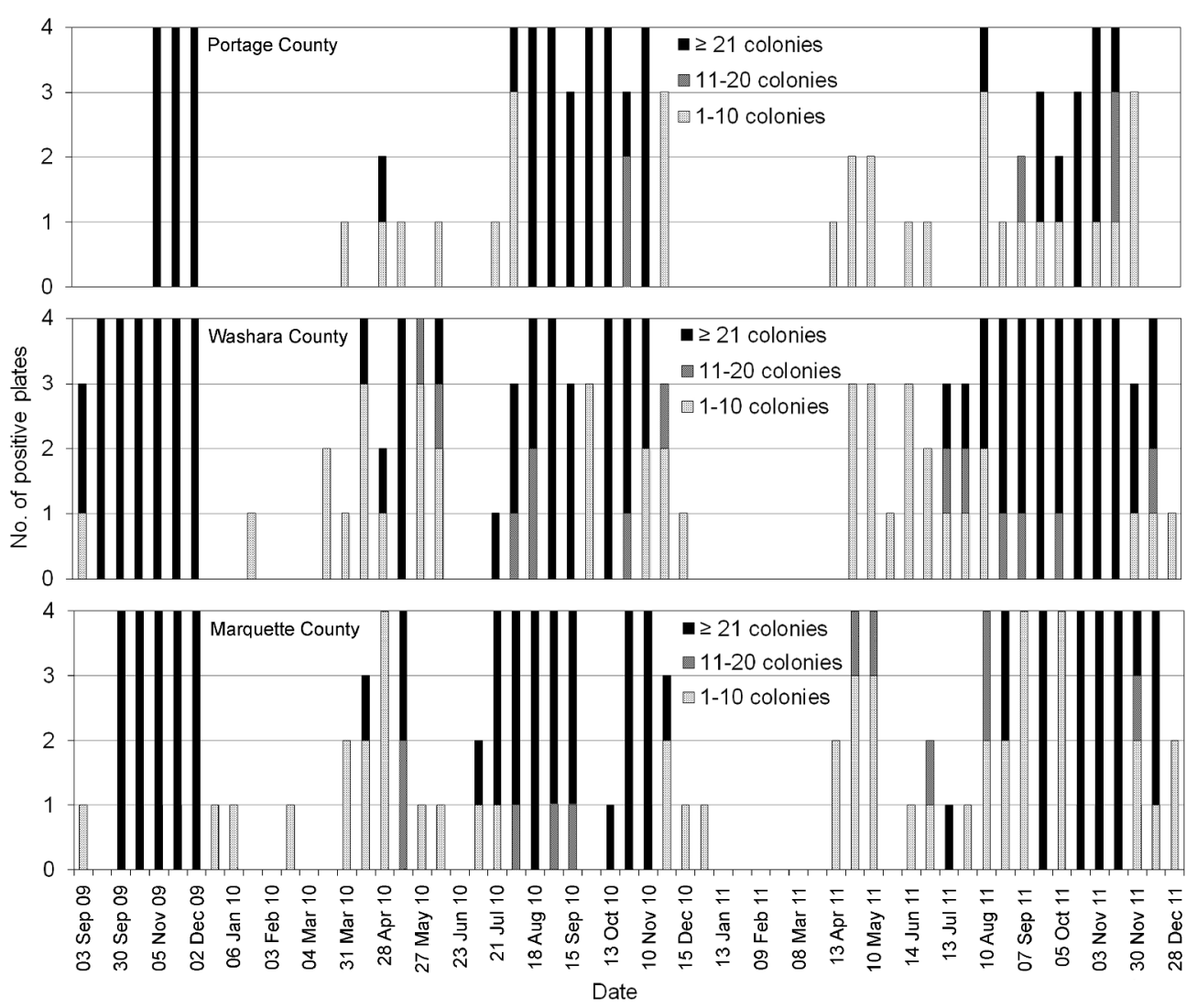

Fig. 1. Numbers of Petri plates of semi-selective agar medium exposed for 1 hour in daylight at each of three infested sites on which the Spiniger asexual stage of Heterobasidion irregulare was detected. Spore trapping did not begin until 5 November 2009 in Portage County, and did not occur in Waushara Co. on 23 June and 8 July 2010

and Portage Co. on 13 July and 26 July 2011 due to harvest activity. Shading of bars indicates the numbers of $H$. irregulare colonies on each plate. 
Table S1. Temperatures during the 1-hour exposure of spore traps at three sites in Wisconsin, and available weather data recorded for the 14 days prior to spore-trapping date at nearby weather stations. Asterisks indicate that weather station records for the respective 14-day period were incomplete.

\begin{tabular}{|c|c|c|c|c|c|c|c|c|c|c|}
\hline \multicolumn{10}{|c|}{ Spore-trapping site, weather station location: Portage County, Stevens Point, WI } & Data for 14 days prior to spore trapping \\
\hline \multirow[t]{2}{*}{$\begin{array}{l}\text { Date of } \\
\text { spore } \\
\text { trapping }\end{array}$} & \multicolumn{2}{|c|}{$\begin{array}{c}\text { Temperature } \\
\text { during spore } \\
\text { trapping } \\
\left({ }^{\circ} \mathrm{C}\right)\end{array}$} & \multicolumn{2}{|c|}{$\begin{array}{l}\text { Minimum } \\
\text { temperature } \\
\text { range } \\
\left({ }^{\circ} \mathrm{C}\right)\end{array}$} & \multicolumn{2}{|c|}{$\begin{array}{l}\text { Maximum } \\
\text { temperature } \\
\text { range } \\
\left({ }^{\circ} \mathrm{C}\right)\end{array}$} & \multirow[t]{2}{*}{$\begin{array}{c}\text { Liquid } \\
\text { precipitation } \\
\text { total } \\
(\mathrm{mm})\end{array}$} & \multirow[t]{2}{*}{$\begin{array}{c}\text { Snowfall } \\
\text { total } \\
(\mathrm{cm})\end{array}$} & \multicolumn{2}{|c|}{$\begin{array}{l}\text { Snow depth } \\
\text { range } \\
\text { (cm) }\end{array}$} \\
\hline & Min & Max & Min & Max & Min & Max & & & Min & Max \\
\hline 03 Sep 09 & - & - & - & - & - & - & - & - & - & - \\
\hline 16 Sep 09 & - & - & - & - & - & - & - & - & - & - \\
\hline 30 Sep 09 & - & - & - & - & - & - & - & - & - & - \\
\hline 14 Oct 09 & - & - & - & - & - & - & - & - & - & - \\
\hline 05 Nov 09 & 1 & 4 & -4 & 9 & 4 & 18 & 47 & 0 & 0 & 0 \\
\hline 20 Nov 09 & 8 & 8 & -5 & 6 & 7 & 19 & 21 & 0 & 0 & 0 \\
\hline 02 Dec 09 & 0 & 0 & -4 & 6 & 2 & 13 & 29 & 0 & 0 & 0 \\
\hline $16 \operatorname{Dec} 09$ & -12 & -11 & -21 & -3 & -13 & 3 & 21 & 23 & 0 & 18 \\
\hline 06 Jan 10 & -16 & -13 & -23 & -3 & -13 & 2 & 38 & 11 & 13 & 15 \\
\hline 20 Jan 10 & -8 & -5 & -19 & -5 & -7 & 1 & 5 & 9 & 15 & 18 \\
\hline 03 Feb 10 & -13 & -11 & -22 & -1 & -15 & 3 & 5* & 7 & 8 & 15 \\
\hline 16 Feb 10 & -5 & -5 & -18 & -7 & -4 & 1 & 10 & 16 & 13 & 20 \\
\hline 04 Mar 10 & -4 & -2 & -14 & -3 & -2 & 7 & 2 & 4 & 13 & 18 \\
\hline 16 Mar 10 & 3 & 3 & -9 & 4 & 4 & 18 & 16 & 0 & 0 & 13 \\
\hline 31 Mar 10 & 12 & 14 & -9 & 4 & 4 & 19 & 0 & 0 & 0 & 0 \\
\hline 14 Apr 10 & 8 & 12 & -6 & 12 & 3 & 27 & 37 & 0 & 0 & 0 \\
\hline 28 Apr 10 & 7 & 10 & -2 & 8 & 11 & 26 & 22 & 0 & 0 & 0 \\
\hline 12 May 10 & 6 & 7 & -2 & 12 & 6 & 26 & 64 & 0 & 0 & 0 \\
\hline 27 May 10 & 18 & 20 & 3 & 21 & 13 & 32 & 5 & 0 & 0 & 0 \\
\hline 09 Jun 10 & 22 & 23 & 10 & 18 & 16 & 31 & 75 & 0 & 0 & 0 \\
\hline 23 Jun 10 & 28 & 29 & 10 & 17 & 17 & 29 & 42 & 0 & 0 & 0 \\
\hline $08 \mathrm{Jul} 10$ & 26 & 28 & 8 & 21 & 22 & 30 & 110 & 0 & 0 & 0 \\
\hline $21 \mathrm{Jul} 10$ & 20 & 22 & 16 & 19 & 25 & 29 & 111 & 0 & 0 & 0 \\
\hline 04 Aug 10 & 22 & 24 & 15 & 21 & 19 & 31 & 72 & 0 & 0 & 0 \\
\hline 18 Aug 10 & 18 & 18 & 12 & 23 & 21 & 31 & 96 & 0 & 0 & 0 \\
\hline 01 Sep 10 & 19 & 21 & 9 & 22 & 22 & 31 & 35 & 0 & 0 & 0 \\
\hline 15 Sep 10 & 13 & 13 & 5 & 16 & 15 & 26 & 47 & 0 & 0 & 0 \\
\hline 30 Sep 10 & 11 & 11 & 3 & 13 & 13 & 23 & 146 & 0 & 0 & 0 \\
\hline 13 Oct 10 & 6 & 7 & 0 & 9 & 11 & 26 & 1 & 0 & 0 & 0 \\
\hline 28 Oct 10 & 4 & 5 & -2 & 13 & 7 & 18 & 51 & 0 & 0 & 0 \\
\hline 10 Nov 10 & 10 & 10 & -4 & 3 & 4 & 18 & 1 & 0 & 0 & 0 \\
\hline $01 \mathrm{Dec} 10$ & -7 & -7 & -11 & 1 & -6 & 7 & 32 & 1 & 0 & 0 \\
\hline $15 \mathrm{Dec} 10$ & -25 & -25 & -24 & -8 & -10 & -1 & 32 & 32 & 0 & 25 \\
\hline $28 \mathrm{Dec} 10$ & -7 & -7 & -24 & -4 & -10 & 1 & 8 & 9 & 20 & 25 \\
\hline
\end{tabular}




\begin{tabular}{|c|c|c|c|c|c|c|c|c|c|c|}
\hline \multicolumn{11}{|c|}{ Spore-trapping site, weather station location: Portage County, Stevens Point, WI (continued) } \\
\hline \multirow[t]{2}{*}{$\begin{array}{l}\text { Date of } \\
\text { spore } \\
\text { trapping }\end{array}$} & \multicolumn{2}{|c|}{$\begin{array}{c}\text { Temperature } \\
\text { during spore } \\
\text { trapping } \\
\left({ }^{\circ} \mathrm{C}\right)\end{array}$} & \multicolumn{2}{|c|}{$\begin{array}{l}\text { Minimum } \\
\text { temperature } \\
\text { range } \\
\left({ }^{\circ} \mathrm{C}\right)\end{array}$} & \multicolumn{2}{|c|}{$\begin{array}{l}\text { Maximum } \\
\text { temperature } \\
\text { range } \\
\left({ }^{\circ} \mathrm{C}\right)\end{array}$} & \multirow[t]{2}{*}{$\begin{array}{c}\text { Liquid } \\
\text { precipitation } \\
\text { total } \\
(\mathrm{mm})\end{array}$} & \multirow[t]{2}{*}{$\begin{array}{c}\text { Snowfall } \\
\text { total } \\
(\mathrm{cm})\end{array}$} & \multicolumn{2}{|c|}{$\begin{array}{c}\text { Snow depth } \\
\text { range } \\
\text { (cm) }\end{array}$} \\
\hline & Min & Max & Min & Max & Min & Max & & & Min & Max \\
\hline 13 Jan 11 & -7 & -7 & -19 & -1 & -13 & 7 & 6 & 8 & 10 & 13 \\
\hline 25 Jan 11 & -7 & -7 & -28 & -7 & -16 & -4 & 12 & 22 & 13 & 23 \\
\hline 09 Feb 11 & -21 & -21 & -23 & -6 & -13 & -1 & 11 & 12 & $20 *$ & $30 *$ \\
\hline 22 Feb 11 & -9 & -9 & -26 & -2 & -13 & 9 & 24 & 42 & 10 & 36 \\
\hline 08 Mar 11 & -1 & -1 & -18 & -3 & -11 & 6 & 5 & 6 & 18 & 30 \\
\hline 24 Mar 11 & -10 & -10 & -12 & 2 & -4 & 12 & 49 & 13 & 0 & 23 \\
\hline 13 Apr 11 & 10 & 10 & -8 & 8 & 3 & 24 & 45 & 0 & 0 & 3 \\
\hline 27 Apr 11 & 5 & 5 & -3 & 4 & 2 & 17 & 60 & 11 & 0 & 8 \\
\hline 10 May 11 & 14 & 14 & -3 & 9 & 4 & 20 & 32 & 0 & 0 & 0 \\
\hline 01 Jun 11 & 16 & 19 & 1 & 15 & 13 & 31 & 34 & 0 & 0 & 0 \\
\hline 14 Jun 11 & 18 & 21 & 7 & 23 & 12 & 34 & 12 & 0 & 0 & 0 \\
\hline 29 Jun 11 & 22 & 24 & 11 & 17 & 17 & 26 & 73 & 0 & 0 & 0 \\
\hline $13 \mathrm{Jul} 11$ & - & - & 12 & 20 & 22 & 33 & 26 & 0 & 0 & 0 \\
\hline 26 Jul 11 & - & - & 12 & 23 & 22 & 33 & 108 & 0 & 0 & 0 \\
\hline 10 Aug 11 & 21 & 33 & 12 & 22 & 22 & 31 & 124 & 0 & 0 & 0 \\
\hline 24 Aug 11 & 25 & 28 & 12 & 18 & 20 & 29 & 20 & 0 & 0 & 0 \\
\hline 07 Sep 11 & 12 & 17 & 5 & 19 & 16 & 31 & 51 & 0 & 0 & 0 \\
\hline 22 Sep 11 & 14 & 14 & 1 & 14 & 12 & 28 & 19 & 0 & 0 & 0 \\
\hline 05 Oct 11 & 12 & 18 & -1 & 8 & 11 & 24 & 45 & 0 & 0 & 0 \\
\hline 19 Oct 11 & 2 & 7 & 2 & 15 & 10 & 26 & 28 & 0 & 0 & 0 \\
\hline 03 Nov 11 & 0 & 1 & -3 & 3 & 6 & 15 & 18 & 0 & 0 & 0 \\
\hline 16 Nov 11 & -1 & -1 & $-4 *$ & 2* & 2 & 13 & 36 & 7 & 0 & 5 \\
\hline 30 Nov 11 & -9 & -5 & -8 & 6 & -1 & 11 & 11 & 0 & 0 & 0 \\
\hline $15 \operatorname{Dec} 11$ & 1 & 2 & -16 & 1 & -8 & 8 & 30 & 2 & 0 & 0 \\
\hline 28 Dec 11 & -10 & -10 & -13 & 1 & -4 & 7 & 8 & 4 & 0 & 3 \\
\hline
\end{tabular}




\begin{tabular}{|c|c|c|c|c|c|c|c|c|c|c|}
\hline \multicolumn{11}{|c|}{ Spore-trapping site, weather station location: Waushara County, Hancock, WI } \\
\hline \multirow[t]{2}{*}{$\begin{array}{l}\text { Date of } \\
\text { spore } \\
\text { trapping }\end{array}$} & \multicolumn{2}{|c|}{$\begin{array}{c}\text { Temperature } \\
\text { during spore } \\
\text { trapping } \\
\left({ }^{\circ} \mathrm{C}\right)\end{array}$} & \multicolumn{2}{|c|}{$\begin{array}{l}\text { Minimum } \\
\text { temperature } \\
\text { range } \\
\left({ }^{\circ} \mathrm{C}\right)\end{array}$} & \multicolumn{2}{|c|}{$\begin{array}{l}\text { Maximum } \\
\text { temperature } \\
\text { range } \\
\left({ }^{\circ} \mathrm{C}\right)\end{array}$} & \multirow[t]{2}{*}{$\begin{array}{c}\text { Liquid } \\
\text { precipitation } \\
\text { total } \\
(\mathrm{mm})\end{array}$} & \multirow[t]{2}{*}{$\begin{array}{c}\text { Snowfall } \\
\text { total } \\
(\mathrm{cm})\end{array}$} & \multicolumn{2}{|c|}{$\begin{array}{l}\text { Snow depth } \\
\text { range } \\
(\mathrm{cm})\end{array}$} \\
\hline & Min & Max & Min & Max & Min & Max & & & Min & Max \\
\hline 03 Sep 09 & - & - & 4 & 17 & 16 & 26 & 25 & 0 & 0 & 0 \\
\hline 16 Sep 09 & - & - & 7 & 13 & 23 & 28 & 0 & 0 & 0 & 0 \\
\hline 30 Sep 09 & - & - & -2 & 14 & 12 & 26 & 5 & 0 & 0 & 0 \\
\hline 14 Oct 09 & 2 & 2 & -5 & 7 & 3 & 14 & 54 & 0 & 0 & 0 \\
\hline 05 Nov 09 & 6 & 7 & -4 & 10 & 4 & 19 & 40 & 0 & 0 & 0 \\
\hline 20 Nov 09 & 9 & 9 & -6 & 6 & 7 & 20 & 21 & 0 & 0 & 0 \\
\hline 02 Dec 09 & 3 & 3 & -5 & 6 & 2 & 14 & 31 & 0 & 0 & 0 \\
\hline 16 Dec 09 & -7 & -6 & $-21^{*}$ & $-3 *$ & $-14^{*}$ & $8^{*}$ & $16^{*}$ & $35 *$ & $0 *$ & $33 *$ \\
\hline 06 Jan 10 & -7 & -7 & -27 & -1 & -14 & 3 & 45 & 8 & 13 & 23 \\
\hline 20 Jan 10 & -5 & -3 & -21 & -5 & -9 & 2 & 3 & 14 & 10 & 25 \\
\hline 03 Feb 10 & -6 & -4 & $-21^{*}$ & $-2^{*}$ & -15 & 3 & $20^{*}$ & 7 & 8 & 18 \\
\hline 16 Feb 10 & -2 & -2 & -21 & -7 & -4 & 0 & 8 & 36 & 18 & 33 \\
\hline 04 Mar 10 & 1 & 1 & -19 & -3 & -4 & 4 & 2 & 5 & 10 & 23 \\
\hline 16 Mar 10 & 6 & 6 & -14 & 4 & 2 & 17 & 16 & 0 & 0 & 10 \\
\hline 31 Mar 10 & 17 & 19 & $-9 *$ & $2^{*}$ & 4 & 20 & 0 & 0 & 0 & 0 \\
\hline 14 Apr 10 & 13 & 16 & -7 & 8 & 3* & $27^{*}$ & 40 & 0 & 0 & 0 \\
\hline $28 \mathrm{Apr} 10$ & 13 & 19 & -3 & 9 & 11 & 27 & 28 & 0 & 0 & 0 \\
\hline 12 May 10 & 8 & 8 & $-3 *$ & $12^{*}$ & 6 & 26 & 58 & 0 & 0 & 0 \\
\hline 27 May 10 & 23 & 25 & 2 & 21 & 14 & 33 & 5 & 0 & 0 & 0 \\
\hline 09 Jun 10 & 22 & 23 & 10 & 17 & $21 *$ & $33 *$ & 58 & 0 & 0 & 0 \\
\hline 23 Jun 10 & 22 & 25 & 9* & $18^{*}$ & 18 & 28 & 62 & 0 & 0 & 0 \\
\hline $08 \mathrm{Jul} 10$ & 23 & 26 & 11 & 22 & 22 & 31 & 161 & 0 & 0 & 0 \\
\hline $21 \mathrm{Jul} 10$ & 26 & 32 & 15 & 19 & 26 & 31 & 152 & 0 & 0 & 0 \\
\hline 04 Aug 10 & 27 & 29 & 13 & 21 & 22 & 32 & 77 & 0 & 0 & 0 \\
\hline 18 Aug 10 & 21 & 21 & 12 & 23 & 22 & 33 & 133 & 0 & 0 & 0 \\
\hline 01 Sep 10 & 25 & 25 & 7 & 22 & 22 & 32 & 3 & 0 & 0 & 0 \\
\hline 15 Sep 10 & 14 & 14 & 5 & 16 & 15 & 26 & 21 & 0 & 0 & 0 \\
\hline 30 Sep 10 & 15 & 15 & 2 & 12 & 13 & 27 & 75 & 0 & 0 & 0 \\
\hline 13 Oct 10 & 9 & 10 & -2 & 9 & 11 & 27 & 1 & 0 & 0 & 0 \\
\hline 28 Oct 10 & 6 & 6 & -3 & 13 & $8^{*}$ & $19 *$ & 31 & 0 & 0 & 0 \\
\hline 10 Nov 10 & 13 & 13 & $-7^{*}$ & 7* & $3^{*}$ & $18^{*}$ & $3^{*}$ & 0 & 0 & 0 \\
\hline 01 Dec 10 & -5 & -5 & $-11^{*}$ & $1^{*}$ & $-4^{*}$ & $10^{*}$ & $19 *$ & $1^{*}$ & $0^{*}$ & $0^{*}$ \\
\hline $15 \operatorname{Dec} 10$ & -15 & -15 & -28 & -9 & -13 & -1 & 13 & 50 & 0 & 46 \\
\hline $28 \mathrm{Dec} 10$ & -3 & -3 & $-28^{*}$ & $-6^{*}$ & -11 & -1 & 8 & 10 & 38 & 48 \\
\hline
\end{tabular}




\begin{tabular}{|c|c|c|c|c|c|c|c|c|c|c|}
\hline \multicolumn{11}{|c|}{ Spore-trapping site, weather station location: Waushara County, Hancock, WI (continued) } \\
\hline \multirow{3}{*}{$\begin{array}{l}\text { Date of } \\
\text { spore } \\
\text { trapping }\end{array}$} & \multirow{2}{*}{\multicolumn{2}{|c|}{$\begin{array}{c}\text { Temperature } \\
\text { during spore } \\
\text { trapping } \\
\left({ }^{\circ} \mathrm{C}\right)\end{array}$}} & \multicolumn{8}{|c|}{ Data for 14 days prior to spore trapping } \\
\hline & & & \multicolumn{2}{|c|}{$\begin{array}{l}\text { Minimum } \\
\text { temperature } \\
\text { range } \\
\left({ }^{\circ} \mathrm{C}\right) \\
\end{array}$} & \multicolumn{2}{|c|}{$\begin{array}{c}\text { Maximum } \\
\text { temperature } \\
\text { range } \\
\left({ }^{\circ} \mathrm{C}\right) \\
\end{array}$} & \multirow[t]{2}{*}{$\begin{array}{c}\text { Liquid } \\
\text { precipitation } \\
\text { total } \\
(\mathrm{mm})\end{array}$} & \multirow[t]{2}{*}{$\begin{array}{c}\text { Snowfall } \\
\text { total } \\
(\mathrm{cm})\end{array}$} & \multicolumn{2}{|c|}{$\begin{array}{l}\text { Snow depth } \\
\text { range } \\
(\mathrm{cm})\end{array}$} \\
\hline & Min & Max & Min & Max & Min & Max & & & Min & Max \\
\hline 13 Jan 11 & -2 & -2 & -22 & -7 & -12 & 6 & 4* & 8* & 3 & 13 \\
\hline 25 Jan 11 & -4 & -4 & $-30^{*}$ & $-7^{*}$ & -16 & -3 & $8 *$ & $22 *$ & 8 & 25 \\
\hline 09 Feb 11 & -15 & -15 & $-22^{*}$ & $-7^{*}$ & $-9 *$ & $-1 *$ & $10 *$ & $28 *$ & 20 & 38 \\
\hline 22 Feb 11 & -4 & -4 & $-29 *$ & $-1^{*}$ & $-12^{*}$ & $11^{*}$ & $19 *$ & $34^{*}$ & 8 & 41 \\
\hline 08 Mar 11 & 2 & 2 & -21 & -3 & -7 & 6 & $6 *$ & $8 *$ & 20 & 43 \\
\hline 24 Mar 11 & -5 & -5 & $-12^{*}$ & 2* & -3 & $11^{*}$ & $48^{*}$ & $10 *$ & 0 & 20 \\
\hline 13 Apr 11 & 18 & 18 & -6 & 8 & 4 & 24 & 49* & 0* & $0 *$ & $3 *$ \\
\hline 27 Apr 11 & 7 & 7 & -4 & 5 & 4 & 17 & $63^{*}$ & $14^{*}$ & 0* & $10 *$ \\
\hline 10 May 11 & 24 & 24 & -4 & 9 & 6 & 20 & 36 & 0 & 0 & 0 \\
\hline 01 Jun 11 & 23 & 27 & 2 & 18 & 9 & 31 & $54 *$ & 0 & 0 & 0 \\
\hline 14 Jun 11 & 23 & 26 & 4 & 25 & 12 & 35 & $25^{*}$ & 0 & 0 & 0 \\
\hline 29 Jun 11 & 26 & 27 & 8 & 16 & $16^{*}$ & $28^{*}$ & $68^{*}$ & 0 & 0 & 0 \\
\hline $13 \mathrm{Jul} 11$ & 23 & 27 & 12 & 22 & 23 & 36 & 11 & 0 & 0 & 0 \\
\hline 26 Jul 11 & 22 & 28 & 12 & 24 & 23 & 36 & 32 & 0 & 0 & 0 \\
\hline 10 Aug 11 & 19 & 33 & 11 & 26 & 23 & 33 & $61^{*}$ & 0 & 0 & 0 \\
\hline 24 Aug 11 & 25 & 27 & 9 & 18 & 24 & 31 & $18^{*}$ & 0 & 0 & 0 \\
\hline 07 Sep 11 & 16 & 21 & 4* & 19 & $17^{*}$ & $32 *$ & $76 *$ & 0 & 0 & 0 \\
\hline 22 Sep 11 & 20 & 20 & 1 & 14 & 14 & 29 & $29 *$ & 0 & 0 & 0 \\
\hline 05 Oct 11 & 16 & 22 & $-1^{*}$ & $11 *$ & $13^{*}$ & $24^{*}$ & $66^{*}$ & 0 & 0 & 0 \\
\hline 19 Oct 11 & 9 & 10 & 1 & 14 & 11 & 27 & 31 & 0 & 0 & 0 \\
\hline 03 Nov 11 & 5 & 6 & -3 & 6 & 7 & 16 & $31^{*}$ & 0 & 0 & 0 \\
\hline 16 Nov 11 & 0 & 2 & -6 & 3 & 2 & 14 & $47^{*}$ & 10 & 0 & 10 \\
\hline 30 Nov 11 & 0 & 2 & -9 & 7 & 2 & 11 & 8 & 0 & 0 & 0 \\
\hline 15 Dec 11 & 0 & 1 & -15 & 1 & -7 & 7 & 23 & 1 & 0 & 0 \\
\hline 28 Dec 11 & -7 & -7 & -14 & -3 & -3 & 7 & 5 & $4^{*}$ & $0 *$ & 5* \\
\hline
\end{tabular}




\begin{tabular}{|c|c|c|c|c|c|c|c|c|c|c|}
\hline \multicolumn{9}{|c|}{ Spore-trapping site, weather station location: Marquette County, Montello , WI } & & \\
\hline \multirow[t]{2}{*}{$\begin{array}{l}\text { Date of } \\
\text { spore } \\
\text { trapping }\end{array}$} & \multicolumn{2}{|c|}{$\begin{array}{c}\text { Temperature } \\
\text { during spore } \\
\text { trapping } \\
\left({ }^{\circ} \mathrm{C}\right)\end{array}$} & \multicolumn{2}{|c|}{$\begin{array}{l}\text { Minimum } \\
\text { temperature } \\
\text { range } \\
\left({ }^{\circ} \mathrm{C}\right)\end{array}$} & \multicolumn{2}{|c|}{$\begin{array}{l}\text { Maximum } \\
\text { temperature } \\
\text { range } \\
\left({ }^{\circ} \mathrm{C}\right)\end{array}$} & \multirow[t]{2}{*}{$\begin{array}{c}\text { Liquid } \\
\text { precipitation } \\
\text { total } \\
(\mathrm{mm})\end{array}$} & \multirow[t]{2}{*}{$\begin{array}{c}\text { Snowfall } \\
\text { total } \\
(\mathrm{cm})\end{array}$} & \multicolumn{2}{|c|}{$\begin{array}{l}\text { Snow depth } \\
\text { range } \\
\text { (cm) }\end{array}$} \\
\hline & Min & Max & Min & Max & Min & Max & & & Min & Max \\
\hline 03 Sep 09 & - & - & 4 & 15 & 17 & 26 & 31 & 0 & 0 & 0 \\
\hline 16 Sep 09 & - & - & 7 & 13 & 22 & 29 & 0 & 0 & 0 & 0 \\
\hline 30 Sep 09 & - & - & -1 & 15 & 13 & 25 & 27 & 0 & 0 & 0 \\
\hline 14 Oct 09 & - & - & -6 & 8 & 4 & 15 & 30 & 0 & 0 & 0 \\
\hline 05 Nov 09 & 9 & 10 & $-3 *$ & 9 & 5 & 19 & 64 & 0 & 0 & 0 \\
\hline 20 Nov 09 & 9 & 9 & -6 & 7 & 7 & 22 & 12 & 0 & 0 & 0 \\
\hline 02 Dec 09 & 3 & 3 & -5 & 6 & 3 & 14 & 30 & 0 & 0 & 0 \\
\hline 16 Dec 09 & -5 & -5 & -22 & -2 & -12 & 3 & 42 & 40 & 0 & 36 \\
\hline 06 Jan 10 & -5 & -3 & -22 & -1 & -13 & 3 & 43 & 12 & 15 & 23 \\
\hline $20 \operatorname{Jan} 10$ & 5 & 5 & -23 & -4 & -8 & 2 & 11 & 10 & 20 & 30 \\
\hline 03 Feb 10 & -4 & -4 & -22 & 1 & -13 & 3 & 16 & 5 & 13 & 20 \\
\hline 16 Feb 10 & -1 & -1 & -21 & -7 & -3 & 1 & 14 & 18 & 15 & 28 \\
\hline 04 Mar 10 & 2 & 2 & -16 & -2 & -2 & 6 & 5 & 5 & 18 & 25 \\
\hline 16 Mar 10 & 13 & 13 & -12 & 4 & 4 & 16 & 12 & 0 & 0 & 18 \\
\hline 31 Mar 10 & 20 & 24 & -8 & 3 & 6 & 19 & 0 & 0 & 0 & 0 \\
\hline 14 Apr 10 & 22 & 25 & -6 & 11 & 4 & 28 & 55 & 3 & 0 & 3 \\
\hline 28 Apr 10 & 22 & 22 & -7 & 9 & 10 & 28 & 41 & 0 & 0 & 0 \\
\hline 12 May 10 & 8 & 8 & -2 & 12 & 7 & 27 & 71 & 0 & 0 & 0 \\
\hline 27 May 10 & 26 & 27 & 3 & 21 & 16 & 33 & 7 & 0 & 0 & 0 \\
\hline 09 Jun 10 & 17 & 20 & 9 & 18 & 18 & 33 & 54 & 0 & 0 & 0 \\
\hline 23 Jun 10 & 21 & 22 & 11 & 18 & 20 & 29 & 78 & 0 & 0 & 0 \\
\hline 08 Jul 10 & 21 & 22 & 8 & 22 & 22 & 30 & 62 & 0 & 0 & 0 \\
\hline $21 \mathrm{Jul} 10$ & 26 & 29 & 16 & 21 & 26 & 31 & 107 & 0 & 0 & 0 \\
\hline 04 Aug 10 & 25 & 25 & 14 & 22 & 23 & 31 & 68 & 0 & 0 & 0 \\
\hline 18 Aug 10 & 24 & 24 & 12 & 22 & 22 & 32 & 112 & 0 & 0 & 0 \\
\hline 01 Sep 10 & 23 & 24 & 8 & 21 & 22 & 33 & 49 & 0 & 0 & 0 \\
\hline 15 Sep 10 & 21 & 21 & 6 & 17 & 16 & 27 & 39 & 0 & 0 & 0 \\
\hline 30 Sep 10 & 18 & 18 & 1 & 14 & 14 & 25 & 19 & 0 & 0 & 0 \\
\hline 13 Oct 10 & 15 & 16 & -2 & 9 & 12 & 28 & 1 & 0 & 0 & 0 \\
\hline 28 Oct 10 & 6 & 6 & -4 & 13 & 11 & 22 & 48 & 0 & 0 & 0 \\
\hline 10 Nov 10 & 15 & 15 & -6 & 4 & 4 & 19 & 0 & 0 & 0 & 0 \\
\hline $01 \mathrm{Dec} 10$ & -5 & -5 & -11 & 2 & -3 & 12 & 20 & 0 & 0 & 0 \\
\hline 15 Dec 10 & -12 & -12 & -27 & -7 & -11 & 2 & 34 & 38 & 0 & 36 \\
\hline $28 \mathrm{Dec} 10$ & -3 & -3 & -27 & -6 & -11 & 2 & 7 & 7 & 28 & 36 \\
\hline
\end{tabular}




\begin{tabular}{|c|c|c|c|c|c|c|c|c|c|c|}
\hline \multicolumn{11}{|c|}{ Spore-trapping site, weather station location: Marquette County, Montello, WI (continued) } \\
\hline \multirow[t]{2}{*}{$\begin{array}{l}\text { Date of } \\
\text { spore } \\
\text { trapping }\end{array}$} & \multicolumn{2}{|c|}{$\begin{array}{c}\text { Temperature } \\
\text { during spore } \\
\text { trapping } \\
\left({ }^{\circ} \mathrm{C}\right) \\
\end{array}$} & \multicolumn{2}{|c|}{$\begin{array}{l}\text { Minimum } \\
\text { temperature } \\
\text { range } \\
\left({ }^{\circ} \mathrm{C}\right)\end{array}$} & \multicolumn{2}{|c|}{$\begin{array}{l}\text { Maximum } \\
\text { temperature } \\
\text { range } \\
\left({ }^{\circ} \mathrm{C}\right) \\
\end{array}$} & \multirow[t]{2}{*}{$\begin{array}{c}\text { Liquid } \\
\text { precipitation } \\
\text { total } \\
(\mathrm{mm})\end{array}$} & \multirow[t]{2}{*}{$\begin{array}{c}\text { Snowfall } \\
\text { total } \\
(\mathrm{cm})\end{array}$} & \multicolumn{2}{|c|}{$\begin{array}{l}\text { Snow depth } \\
\text { range } \\
(\mathrm{cm})\end{array}$} \\
\hline & Min & Max & Min & Max & Min & Max & & & Min & Max \\
\hline 13 Jan 11 & -5 & -5 & -21 & 1 & -10 & 7 & 7 & 8 & 15 & 20 \\
\hline 25 Jan 11 & -3 & -3 & -29 & -7 & -14 & -2 & 17 & 24 & 18 & 36 \\
\hline 09 Feb 11 & -13 & -13 & -23 & -6 & -11 & 0 & 30 & 30 & 30 & 51 \\
\hline 22 Feb 11 & -4 & -4 & -28 & 0 & -11 & 12 & 28 & 18 & 18 & 46 \\
\hline 08 Mar 11 & 2 & 2 & -18 & -2 & -9 & 6 & 4 & 9 & 23 & 36 \\
\hline 24 Mar 11 & -2 & -2 & -11 & 2 & -2 & 14 & 60 & 3 & 0 & 30 \\
\hline 13 Apr 11 & 20 & 24 & -7 & 9 & 6 & 27 & 22 & 0 & 0 & 0 \\
\hline 27 Apr 11 & 7 & 7 & -3 & 4 & 2 & 22 & 87 & 13 & 0 & 13 \\
\hline 10 May 11 & 24 & 24 & -3 & 9 & 6 & 21 & 37 & 0 & 0 & 0 \\
\hline 01 Jun 11 & 23 & 27 & 1 & 17 & 10 & 32 & 54 & 0 & 0 & 0 \\
\hline 14 Jun 11 & 25 & 30 & 7 & 24 & 13 & 34 & 45 & 0 & 0 & 0 \\
\hline 29 Jun 11 & 25 & 26 & 10 & 17 & 16 & 27 & 94 & 0 & 0 & 0 \\
\hline $13 \mathrm{Jul} 11$ & 20 & 28 & 14 & 21 & 26 & 34 & 20 & 0 & 0 & 0 \\
\hline $26 \mathrm{Jul} 11$ & 25 & 33 & 13 & 24 & 23 & 35 & 31 & 0 & 0 & 0 \\
\hline 10 Aug 11 & 18 & 33 & 14 & 23 & 23 & 32 & 43 & 0 & 0 & 0 \\
\hline 24 Aug 11 & 23 & 29 & 9 & 18 & 23 & 31 & 8 & 0 & 0 & 0 \\
\hline 07 Sep 11 & 17 & 18 & 3 & 20 & 17 & 33 & 24 & 0 & 0 & 0 \\
\hline 22 Sep 11 & 13 & 13 & 1 & 14 & 14 & 30 & 19 & 0 & 0 & 0 \\
\hline 05 Oct 11 & 20 & 23 & -2 & 10 & 14 & 24 & 43 & 0 & 0 & 0 \\
\hline 19 Oct 11 & 8 & 9 & 1 & 12 & 12 & 27 & 30 & 0 & 0 & 0 \\
\hline 03 Nov 11 & 7 & 7 & -4 & 4 & 6 & 18 & 34 & 0 & 0 & 0 \\
\hline 16 Nov 11 & 1 & 4 & -6 & 2 & 3 & 15 & 93 & 10 & 0 & 10 \\
\hline 30 Nov 11 & 1 & 3 & -8 & 6 & 0 & 12 & 16 & 0 & 0 & 0 \\
\hline $15 \operatorname{Dec} 11$ & 0 & 1 & -17 & 2 & -6 & 9 & 30 & 0 & 0 & 0 \\
\hline $28 \mathrm{Dec} 11$ & -4 & -4 & -13 & 2 & -3 & 9 & 7 & 1 & 0 & 3 \\
\hline
\end{tabular}

